\title{
PENGARUH QUANTUM TEACHING TERHADAP HASIL BELAJAR DAN RETENSI SISWA PADA MATA PELAJARAN IPA DI SD SW. BETANIA MEDAN
}

\author{
Lidia Simanihuruk \\ Surel : meifleur@yahoo.com
}

\begin{abstract}
ABSTRAK
Tujuan dari penelitian ini adalah untuk mengetahui perbedaan hasil belajar IPA antara siswa yang diajar dengan menggunakan Quantum Teaching dibandingkan model pembelajaran konvensional di SD SW. Betania Medan. Penelitian eksperimen semu ini menggunakan rancangan model Group Pretespostes. Data dianalisis menggunakan uji independent sampel $t$ tes dengan taraf signifikan $(\alpha)=0,05$. Sampel penelitian ini merupakan siswa kelas IV di SD Sw. Betania Medan. Penarikan sampel dilakukan secara purposif. Teknik pengumpulan data menggunakan instrumen yang terdiri atas tes hasil belajar dan tes retensi yang berbentuk pilihan berganda sebanyak 20 soal dan sudah valid dan reliabel. Hasil penelitian diperoleh Medan pada materi pelajaran energi adalah hasil belajar IPA siswa yang diajar dengan menggunakan Quantum Teaching lebih tinggi dibandingkan dengan menggunakan model pembelajaran konvensional, retensi siswa yang diajar dengan menggunakan Quantum Teaching lebih tinggi daripada yang diajar dengan menggunakan model pembelajaran konvensional.
\end{abstract}

Kata Kunci : Quantum Teaching, Hasil Belajar, Retensi.

\section{PENDAHULUAN}

Pendidikan IPA di sekolah dasar bermanfaat bagi siswa untuk mempelajari diri sendiri dan alam sekitar. Pendidikan IPA menekankan pada pemberian pengalaman langsung dan kegiatan praktis untuk mengembangkan kompetensi agar siswa mampu menjelajahi dan memahami alam sekitar secara ilmiah (anonim, 2003). Kedudukan mata pelajaran IPA (sain) dalam dunia pendidikan sangat penting karena mata pelajaran IPA merupakan salah satu mata pelajaran wajib dalam setiap jenjang pendidikan/ pada jenjang pendidikan sekolah dasar (SD) mata pelajaran IPA merupakan dasar untuk mempelajari cabang-cabang mata pelajaran IPA seperti biologi, kimia, dan fisika yang ada di tingkat pendidikan yang lebih tinggi. Ada beberapa alasan yang menyebabkan mata pelajaran ini dimasukkan ke dalam kurikulum sekolah. Alasan itu dapat digolongkan menjadi empat golongan yaitu : IPA berfaedah bagi suatu bangsa, bila diajarkan dengan cara yang tepat maka IPA memberikan kesempatan berpikir bila diajarkan melalui perobaanpercobaan maka pelajaran ini tidaklah bersifat hafalan belaka dan mata pelajaran ini mempunyai nilainilai pendidikan yaitu : mempunyai potensi yang dapat membentuk kepribadian anak secara keseluruhan 
(Samatowa, 2006).

Pembelajaran IPA membuat siswa menyadari keterbatasan pengetahuan mereka, memiliki rasa ingin tahu untuk menggali berbagai pengetahuan baru dan akhirnya dapat mengaplikasikannya dalam kehidupan mereka (Samatowa, 2006). Selain itu pembelajaran IPA di jenjang Sekolah Dasar (SD) memegang peranan penting bagi pembelajaran IPA pada jenjangjenjang berikutnya sebab pengalaman belajar IPA di SD bukan hanya mempengaruhi aspek pengetahuan siswa tentang IPA tetapi juga mempengaruhi minat siswa untuk belajar IPA pada jenjang berikutnya. Pembelajran IPA di SD harus memberikan dasar-dasar pengetahuan dan keterampilan IPA yang diperlukan untuk belajar IPA pada jenjang berikutnya serta bisa membangkitkan sikap dan minat siswa untuk terus belajar IPA (Widodo, 2009).

\section{Pembelajaran}

yang

sebenarnya dilaksanakan oleh guruguru di SD Sw. Betania masih menggunakan pembelajaran tradisional atau konvensional. Pada saat pembelajaran berlangsung guru menjelaskan semua materi yang ada di buku sehingga membuat siswa cepat merasa bosan dan tidak tertarik dengan materi yang disampaikan. Bila penyampaian materi dilakukan di luar ruang kelas atau di lingkungan sekitar sekolah dapat membuat siswa lebih tertarik terhadap mata pelajaran IPA. Penggunaan alat bantu pada saat guru menyampaikan materi pelajaran kurang lengkap sehingga siswa sukar untuk memahami dan menyerap materi yang disampaikan. Hal ini sesuai dengan pendapat Darmodjo dan Kaligis (1993) yang menyatakan bahwa :

Keefektifan daya serap anak didik terhadap bahan pelajaran yang sulit dan rumit dapat terjadi dengan bantuan alat bantu. Kesulitan anak didik memahami konsep dan prinsip tertentu dapat diatasi dengan bantuan alat bantu. Bahkan alat bantu diakui dapat melahirkna umpan balik yang baik dari anak didik.

Setelah guru merasa materi yang disampaikan cukup, siswa diberikan tugas untuk mengerjakan soal latihan yang ada di buku paket atau lembar kerja siswa atau soalsoal ujian nasional sebelumnya di dalam kelas atau dikerjakan di rumah. Bila siswa tidak disuruh mengerjakan soal latihan maka siswa disuruh mencatat kesimpulan yang telah ditulis guru di papan tulis.

Berdasarkan pengamatan terhadap data nilai siswa pada beberapa tahun dapat diketahui bahwa hasil belajar siswa mencapai nilai KKM yang telah ditetapkan oleh SD Sw. Betania yaitu sebesar 7,00. Data hasil belajar tersebut dapat dilihat di tabel berikut: 
Tabel Hasil Belajar IPA Siswa SD Sw. Betania Medan

\begin{tabular}{|c|c|}
\hline Tahun Pelajaran & Nilai Rata-rata \\
\hline $2006 / 2007$ & 6,50 \\
\hline $2007 / 2008$ & 5,98 \\
\hline $2008 / 2009$ & 5,60 \\
\hline $2009 / 2010$ & 6,50 \\
\hline $2010 / 2011$ & 6,90 \\
\hline
\end{tabular}

Berdasarkan data pada tabel di atas menunjukkan bahwa hasil belajar siswa belum memuaskan. Rendahnya hasil belajar siswa ini disebabkan oleh beberapa faktor baik yang berasal dari luar (faktor eksternal) maupun dari dalam diri siswa (faktor internal). Beberapa faktor yang berasal dari luar dapat berupa model pembelajaran yang digunakan oleh guru, suasana kelas dan fasilitas yang diberikan. Sedangkan faktor yang berasal dari dalam diri siswa dapat berupa rasa tertarik siswa terhadap mata pelajaran, motivasi, retensi dan lain sebagainya. Hal ini sesuai dengan pernyataan Pepak dalam Parhusip (2009) yang menyarakan bahwa : keberhasilan studi siswa dipengaruhi oleh banyak faktor yang berasal dari luar dan dalam diri siswa. Faktor luar misalnya peran guru, ingin mendapat manfaat praktis dari pelajaran, ingin mendapat penghargaan dari teman terutama guru, ingin mendapat nilai yang baik sebagai bukti "mampu berbuat", lingkungan sosial yang membangun dalam kelompok, lingkungan fisik yang memberi suasana nyaman, tekanan, kompetensi, termasuk fasilitas belajar yang memadai. Sedangkan faktor dalam mencakup minat, motivasi berprestasi dan sebagainya.

Guru sebagai subjek pembelajar berhubungan langsung denga siswa dan memiliki peranan penting dalam acara pembelajaran salah saru adalah melakukan pembelajaran sesuai dengan berbagai model pembelajaran yang disesuaikan dengan kondisi siswa, bahan belajar dan kondisi sekolah setempat (Djamarah, 2002). Penyesuaian tersebut dilakukan untuk peningkatan mutu belajar. Bial pemilihan mnodel pembelajaran yang tepat dapat membuat siswa tertarik terhadap mata pelajaran IPA sehingga hasil belajar siswa dapat meningkat.

Berdasarkan uraian di atas salah satu cara untuk meningkatkan hasil belajar adalah melalui Quantum Teaching. Model pembelajaran ini menekankan kegiatannya pada pengembangan potensi manusia secara optimal melalui cara-cara yang sangat manusiawi yaitu : mudah, menyenangkan dan memberdayakan. Model pembelajaran ini mengambil bentuk "simponi" dalam pembelajaran yang membagi unsur-unsur pembentuknya menjadi dua kategori yaitu terdiri dari konteks dan isi. Konteks berupa penyiapan kondisi bagi penyelenggara pembelajaran yang berkualitas sedangkan isi merupakan penyajian materi pelajaran (DePorter, 2003).

Menyiapkan kondisi pembelajaran di ruang kelas akan 
membuat siswa merasa nyaman, tidak merasa terancam, dan tidak merasa bosan. Penyampaian materi yang tepat mempengaruhi siswa untuk mengingat hasil belajar (retensi). Tingat retensi siswa akan meningkat jika siswa memahami topik pelajaran melalui beragam organ indera. Hal ini dapat membuat pola dan mengumpulkan banyak informasi di otak mereka dengan cara memberikan pengalaman yang kompleks dan kaya. Sehingga tingkat retensi siswa untuk mengingat materi pelajaran tidak rendah dan membuat materu yang telah diterima tidak cepat dilupakan (Odzen, 2008).

Adapun yang menjadi tujuan dari penelitian ini untuk mengetahui : (1) perbedaan hasil belajar IPA antara siswa yang diajar dengan menggunakan Quantum Teaching dibandingkan model pembelajaran konvensional, (2) perbedaan retensi sisiwa yang diajar dengan menggunakan Quantum Teaching dibandingkan dengan siswa yang diajar dengan menggunakan model pembelajaran konvesional di SD SW. Betania Medan.

\section{METODE PENELITIAN}

Variabel dalam penelitian ini ada dua jenis yaitu : variabel bebas dan variabel terikat. Variabel bebas merupakan varibel yang menjelaskan atau mempengaruhi variabel yang lain yaitu model pembelajaran Quantum Teaching. Sedangkan variabel terikat adalah hasil akibat dari pengaruh variabel bebas yaitu : hasil belajar siswa dan variabel terikat kedua adalah retensi siswa pada materi pelajaran benda.

Defenisi Operasional

Untuk mempermudah pemahaman tentang teknis penelitian yang akan dilakukan berikut ini disampaikan operasional variabel yang akan digunakan di dalam penelitian :

a. Model pembelajaran Quantum Teaching merupakan model pembelajaran yang menciptakan lingkungan belajar yang efektif sehingga mengubah kemampuan dan bakat alamiah siswa menjadi cahaya yang akan bermanfaat bagi mereka sendiri dan bagi orang lain.

b. Hasil belajar adalah hasil yang dapat diukur menggunakan alat pengukuran yaitu berupa tes tertulis dan tertuang dalam bentuk angka.

c. Retensi (ingatan) adalah penarikan kembali informasi yang pernah diperoleh sebelumnya.

Berdasarkan permasalahan dan rumusan masalah penelitian yang dikemukakan makan penelitian ini dikategorikan sebagai penelitian kuantitatif eksperimental dengan menggunakan desain eksperimen semu dengan model Group Pretes dan Postes designe.

Sampel dalam penelitian ini adalah seluruh siswa kelas IV yang terdiri dari dua kelas yaitu kelas IVA dan IV B dimana masing-masing kelas terdiri dari 33 orang siswa dan 26 orang siswa. Teknik pengambilan sampel dalam penelitian ini 
dilakukan secara purposive sampling terhadap dua kelas sampel. Sehingga satu kelas akan menjadi kelas eksperimen dan satu kelas lagi menjadi kelas kontrol.

Dalam penelitian ini digunakan beberapa alat untuk mengumpulkan data yaitu : tes hasil belajar, lembar aktivitas siswa dan lembar respon siswa terhadap pembelajaran yang dilakukan dengan Quantum Teaching.

Penelitian ini menggunakan desain eksperimen semu (quasy experiment) dengan model Group Pretes dan Postes designe. Dari kedua sampel tersebut terlebih dahulu diberikan tes awal (pretes) sebelum dilakukannya pembelajaran. Tes awal tersebut diberikan untuk mengetahui kemampuan awal siswa.

Selanjutnya diberikan perlakukan untuk kedua kelas, pada kelas eksperimen dilakukan pengajaran dengan model pembelajaran Quantum Teaching, sedangkan pada kelas kontrol diberikan pengajaran secara konvensional. Setelah pembelajaran dilakukan diberikan postes utnuk mengetahui kemampuan akhir siswa. Tiga minggu setelah pembelajaran dilakukan uji retensi, hal ini dilakukan untuk mengetahui tingkat retensi siswa. Soal yang diberikan untuk menguji retensi siswa adalah soal yang sama dengan soal postes.

Dalam penelitian ini metode analisis data yang digunakan adalah menggunakan teknik analisis T-tes dengan menggunakan program SPSS 17.0, dimana pada analisis ini akan dibandingkan antara pre tes dan pos tes setelah diberikan perlakuan. Dan membandingkan retensi antar ke dua sampel setelah 3 minggu perlakuan diberikan.

\section{HASIL PENELITIAN DAN PEMBAHASAN}

a. Uji Normalitas

Normalitas data diuji dengan teknik kolmogorov-smirnov yang dihitung dengan menggunakan program SPSS 17.0. Suatu data dikatakan berdistirbusi normal jika nilai probabilitas (signifikan) $>0,05$. Pengujian normalitas data dilakukan pada data postes dan data retensi hasil belajar siswa. Pada kelas eksperimen memiliki tingkat signifikan atau nilai probabilitas sebesar 0,27. Pada kelas kontrol menunjukkan bahwa data postes siswa memiliki tingkat signifikansi atau nilai probabilitas 0,78. Dengan demikian baik kelas eksperimen maupun kelas kontrol memiliki nilai probabilitas atau tingkat signifikansi yang lebih besar dari 0,05 maka bisa dikatakan bahwa distribusi kedua kelas adalah normal.

Data retensi hasil belajar siswa pada kelas eksperimen memiliki tingkat signifikansi atau nilai probabilitas sebesar 0,67 sedangkan di kelas kontrol sebesar 0,84. Dengan demikian baik kelas eksperimen dan kelas kontrol memiliki nilai probabilitas yang lebih besar dari 0,05 maka bisa dikatakan bahwa distribusi kedua kelas adalah normal. 
b. Uji Homogenitas

Data postes memiliki nilai probabilitas sebesar 0,11. Nilai signifikansi tersebut lebih besar dari 0,05 dari hal ini dapat diartikan bahwa data postes siswa pada kedua kelas baik kelas eksperimen maupun kontrol memiliki varian populasi yang homogen atau sama.

Data retensi hasil belajar siswa diperoleh nilai probabilitas atau signifikansi sebesar 0,92. Nilai signifikansi tersebut lebih besar dari 0,05 dari hal ini dapat diartikan bahwa data retensi hasil belajar siswa pada kedua kelas baik kelas eksperimen dan kontrol memiliki varians populasi yang homogen.

c. Analisis Data

Setelah diketahui varians berasal dari populasi yang sama maka dapat dilakukan uji hipotesis dengan menggunakan analisis Independent Sampel $t$ test. Nilai t yang diperoleh adalah sebesar 4,57 untuk hasil belajar setelah dilakukan pembelajaran dengan nilai probabilitas atau signifikansi sebesar 0,00. Karena nilai probabilitas $(0,00)<0,05$ maka $\mathrm{H}_{0}$ ditolak dengan kata lain rata-rata hasil belajar siswa yang diajar dengan menggunakan model pembelajaran Quantum Teaching lebih tinggi dari pada hasil belajar siswa yang diajar dengan menggunakan model pembelajaran konvensional.

Nilai t yang diperoleh sebesar 4,88. Di mana nilai probabilitas atau signifikansi sebesar 0,00 . Karena nilai probabilitas atau signifikansi $(0,00)<0,05$ maka $\mathrm{H}_{0}$ ditolak. Dengan kata lain rata-rata retensi hasil belajar siswa yang diajar dengan menggunakan model pembelajaran Quantum Teaching lebih tinggi dari pada hasil belajar siswa yang diajar dengan menggunakan model pembelajaran konvensional.

\section{Pembahasan}

Berdasarkan hasil temuan peneliti dari hasil postes siswa diperoleh ratarata hasil belajar IPA yang diajar dengan menggunakan model Quantum Teaching sebesar 82,70 sedangkan rata-rata hasil belajar IPA dengan menggunakan model pembelaajran konvensional sebesar 67,92 . Hal ini berarti ada perbedaan hasil belajar IPA pada ke dua kelas sampel yang diberikan perlakuan yang berbeda. Pernbedaan hasil belajar tersebut juga dapat dibuktikan dengan hasil pengujian hipotesis menggunakan analisis independent sampel $\mathrm{t}$ test dengan menggunakan program SPSS 17.0. hasil perhitungan menunjukkan bahwa nilai probabilitas atau signifikansi $<0,005$ maka dapat diartikan bahwa rata-rata hasil belajar siswa yang diajar dengan menggunakan model pembelajaran Quantum Teaching lebih tinggi dari pada hasil belajar siswa yang diajar dengan menggunakan model pembelajaran konvensional.

Hasil penelitian ini sesuai dengan hasil penelitian yang telah dilakukan 
oleh Parhusip (2009) dengan menggunakan strategi pembelajaran Quantum Teaching pada mata pelajaran matematikan diketahui bahwa rata-rata hasil belajar siswa yang diajar dengan menggunakan strategi pembelajaran Quantum Teaching lebih tinggi dibandingkan dengan rata-rata hasil belajar siswa yang diajar denganmenggunakan strategi pembelajaran ekspositori. Hal ini sesuai dengan penelitian yang telah dilakukan oleh Siregar (2006) menunjukkan hasil belajar siswa pada mata peljaran agama yang diajar dengan menggunakan strategi pembelajaran Quantum Teaching lebih baik dibandingkan dengan hasil belajar siswa yang diajar dengan menggunakan strategi pembelajaran tradisional. Dengan demikian strategi pembelajaran Quantum Teaching lebih efektif diterapkan. Begitu juga dengan penelitian yang telah dilakukan oleh siregar (2010) pada mata pelajaran IPA semester II dapat diketahui bahwa terdapat peningkatan terhadap hasil belajar siswa kelas IV SDN 101807 Candi Rejo yang diajar dengan menggunakan Quantum Teaching. Dengan demikian Quantum Teaching dapat meningkatkan keefektifan pembelajaran.

Berdasarkan hasil temuan peneliti dari hasil postes siswa diperoleh ratarata retensi hasil belajar IPA yang diajar dengan menggunakan model Quantum Teaching sebesar 70,36 sedangkan rata-rata retensi hasil belajar siswa IPA yang diajar dengan menggunakan model pembelajaran konvensional sebesar 53,50. Hal ini berarti ada perbedaan retensi hasil belajar IPA pada ke dua kelas sampel yang diberikan perlakuan yang berbeda. Perbedaan hasil belajar tersebut juga dapat dibuktikan dengan hasil pengujian hipotesis menggunakan analisis Independent Sampel t test dengan menggunakan program SPSS 17.0. Hasil perhitungan menunjukkan bahwa nilai probabilitas atau signifikansi $<0,005$ maka dapat diartikan bahwa rata-rata retensi hasil belajar siswa yang diajar dengan menggunakan model pembelajaran Quantum Teaching lebih tinggi dari pada hasil belajar siswa yang diajar dengan menggunakan model pembelajaran konvensional.

Perbedaan retensi tersebut dikarenakan pada kelas eskperimen pembelajaran dilakukan dengan menggunakan model pembelajaran Quantum Teaching. Model pembelajaran ini bukan hanya membuat suasana belajar yang menyenangkan, memperhatikan gaya belajar siswa, tetapi juga dapat memaksimalkan ingatan siswa. Pada langkah kelima "ulangi" siswa diberikan kesempatan untuk mengulangi materi yang telah diberikan. Salah satu cara yang dilakukan pada penelitian ini adalah dengan melakukan tanya jawab mengenai sumber energi panas kemudian siswa disuruh untuk menuliskan sumber energi panas yang ditanyakan oleh guru setelah siswa selesai menuliskannya kemudian guru melakukan tanya 
jawab mengenai perpindahan energi panas selanjutnya siswa disuruh kembali menuliskan perpindahan energi panas, begitu juga halnya yang dilakukan dengan materi sub pokok bahasan energi bunyi.

Dari beberapa kegiatan tersebut tanpa disadari siswa telah diajak untuk mengulang-ulang materi sehingga membuat siswa cepat mengingat konsep dari materi yang disampaikan. Karena tidak semua siswa bisa cepat mengingat bila materi diajarkan secara langsung tetapi siswa yang cepat mengerti dan mengingat materi bila siswa membuktikannya sendiri melalui percobaan. Mungkin ada juga sebagian siswa yang bisa mudah memahami dan mengingat materi bila menuliskan kembali dan membacakan kesimpulan yang telah dituliskannya.

Pada kelas yang dibelajarkan dengan model konvensional siswa dijadikan sebagai objek pembelajaran. Keadaan ini membuat siswa kurang banyak bekerja selama mengikuti pembelajaran. Siswa hanya mendengarkan penjelasan guru secara langsung, kegiatan lain yang dilakukan yaitu siswa disuruh untuk mengerjakan soal yang ada di lembar kerja siswa di kelas atau di rumah. Dengan kegiatan yang seperti itu siswa menjadi terlatih untuk mengerjakan soal latihan namun belum bisa memahami dan mengingat materi yang diajarkan.

\section{SIMPULAN}

Beberapa kesimpulan yang dapat diperoleh dari hasil pengujian hipotesis adalah sebagai berikut :

a. Hasil belajar siswa yang diajar dengan menggunakan Quantum Teaching lebih tinggi dari siswa yang diajar dengan menggunakan model pembelajaran konvensional pada mata pelajaran IPA di sekolah SD Sw. Betania pada materi energi pada pokok bahasan energi panas dan energi bunyi.

b. Retensi siswa yang diajar dengan menggunakan Quantum Teaching lebih tinggi dari siswa yang diajar dengan menggunakan model pembelajaran konvensional pada mata pelajaran IPA di sekolah SD Sw. Betania pada materi energi pada pokok bahasan energi panas dan energi bunyi.

\section{DAFTAR RUJUKAN}

Daryanto. 2009. Panduan Proses Pembelajaran Kreatif Dan Inovatif. Jakarta : AV. Publiser.

De Porter, B dan Hernacki. M. 2010. Quantum Learning: Membiasakan Belajar Nyaman dan Menyenangkan, Terjemahan Alwiyah Abdurrahman. Bandung : Kaifa.

Dimyanti dan Mudjiono. 2006. Belajar dan Pembelajaran. Jakarta : PT. Rineka Cipta.

Parhusip, B. 2008. Pengaruh Strategi Pembelajaran

Quantum 
Teaching dan Motivasi

Berprestasi Terhadap Hasil

Belajar Matematika Siswa SMP Negeri 2 Nainggolan, Medan : Prenada Media Group. Sanjaya. 2007. Strategi Pembelajaran Berorientasi Standar Proses Pendidikan, Jakarta : Kencana Pradana Media Group.

Sardiman. 2007. Interaksi dan Motivasi Belajar Mengajar, Jakarta : PT. Raja Grafindo Persada.
Suprijono. 2010. Cooperative Learning dan Aplikasi PAIKEM, Yogyakarta : Pustaka Pelajar.

Suyanto, A. 2008. Psikologi Umum. Jakarta : PT. Bumi Aksara.

Widodo, A. 2009. Peningkatan Kemampuan Mahasiswa PGSD dalam Mengajukan Pertanyaan Produktif Untuk Mendukung Pembelajaran IPA Berbasis Inkuiri, Jurnal Pendidikan, Volume 10, Nomor 1: 21-29. 